\title{
Tolerance Induction Ameliorates Allograft Vasculopathy in Rat Aortic Transplants Influence of Fas-mediated Apoptosis
}

\author{
Levent M. Akyürek, ${ }^{\star}$ Cecilia Johnsson,, Dirk Lange, ${ }^{\ddagger}$ Patrik Georgii-Hemming, ${ }^{\star}$ Erik Larsson, ${ }^{\star}$ Bengt C. Fellström, ${ }^{\S}$ \\ Keiko Funa, and Gunnar Tufveson₹ \\ $*$ Department of Pathology, ${ }^{\ddagger}$ Department of Transplantation Surgery, and ${ }^{\S}$ Department of Medicine, University Hospital, S-751 85 \\ Uppsala, Sweden; and ${ }^{\|}$Ludwig Institute for Cancer Research, Biomedical Centre, S-751 24 Uppsala, Sweden
}

\begin{abstract}
Based on successful induction of donor-specific unresponsiveness by alloantigenic stimulation in several animal models of acute rejection, we hypothesized that similar immune manipulations would also inhibit the evolution of chronic rejection and transplant vasculopathy. To induce immune tolerance, DA rats received a PVG heart allograft and were immunosuppressed with cyclosporine for $30 \mathrm{~d}$. At day 100 the animals were challenged with a PVG aortic allograft after either 1 or $18 \mathrm{~h}$ of cold ischemia. $8 \mathrm{wk}$ after the aortic transplantation, the grafts were investigated for morphological changes, infiltrating cells, apoptosis, and Fas-Fas ligand expression. Control allografts showed advanced transplant arteriosclerosis, whereas tolerance-induced aortic allografts displayed reduced neointimal formation, less medial atrophy, fewer apoptotic cells, and fewer Fas- and FasL-expressing cells. Prolonged ischemic storage time did not profoundly alter the morphological changes of the allografts. Fas expression was found in T cells, macrophages, vascular smooth muscle cells, and endothelial cells, whereas FasL was expressed mainly by $T$ cells and macrophages. FasL mRNA expression was evident throughout the entire allograft wall. In conclusion, induction of allospecific tolerance can effectively prevent transplant arteriosclerosis. Cold ischemia damage does not abrogate the beneficial effect of tolerance, but creates a separate identity of mainly endothelial lesions. Furthermore, Fas-mediated apoptosis appears to be involved in the pathological lesions seen in chronic rejection. (J. Clin. Invest. 1998. 101:2889-2899.) Key words: chronic rejection - arteriosclerosis • ischemia • cyclosporine $\bullet$ Fas
\end{abstract}

Address correspondence to Dr. Levent M. Akyürek, Cardiovascular Research Center, University of Michigan, 7200 MSRB III, 1150 West Medical Center Drive, Ann Arbor, MI 48109-0644. Phone: 313-7635115; FAX: 313-763-4851; E-mail: lakyurek@umich.edu

L.M. Akyürek's present address is Cardiovascular Research Center, University of Michigan, Ann Arbor, MI 48109-0644, and K. Funa's present address is Department of Anatomy and Cell Biology, Göteborg University, S-413 90 Göteborg, Sweden.

Received for publication 11 July 1997 and accepted in revised form 7 April 1998.

J. Clin. Invest.

(C) The American Society for Clinical Investigation, Inc. 0021-9738/98/06/2889/11 \$2.00

Volume 101, Number 12, June 1998, 2889-2899

http://www.jci.org

\section{Introduction}

Chronic rejection constitutes a major problem in organ transplantation. The main features of chronic rejection are vasculopathy, interstitial fibrosis, and a gradual decline of organ function. All vascularized organ transplants share these features to varying degrees. The phenomenon of chronic rejection has been linked to both immunological and nonimmunological causes (1) and a synergistic relationship between several factors cannot be excluded. Chronic rejection of aortic allografts is characterized mainly by luminal narrowing, medial atrophy, and mononuclear cell infiltration. Syngeneic aortic grafts subjected to a longer period of cold ischemia also show intimal lesions with smooth muscle cell (SMC) ${ }^{1}$ proliferation (2). Bone marrow chimeras, made with the appropriate organ donor, do not develop chronic rejection but do express only minimal lesions in the grafted tissue $(3,4)$. On the contrary, permanent graft survival induced by immunosuppression does not protect against development of chronic rejection $(5,6)$. Immunosuppressive treatment of aortic allograft recipients may delay, but not prevent, the development of lesions compatible with chronic rejection (7). Conflicting reports exist regarding the influence of pretreatment by antigen exposure protocols, with or without immunosuppression, on chronic rejection in a subsequent graft (8-12). However, none of these reports have used a graft type where the lesions can be assessed quantitatively. An adequate model for quantitative and morphological measurements is the aorta graft model, which also offers the possibility to analyze mechanisms of vascular remodeling (13).

Despite an increasing number of studies suggesting that cell-mediated immunity is important to allograft arteriopathy, the influence by and the pathogenesis of graft cell death is uncertain. New insights into the immunomodulatory mechanisms by which $\mathrm{T}$ cells, central to the rejection process, kill target cells have recently been provided. In vitro, $\mathrm{CD}^{+} \mathrm{T}$ cells induce apoptosis of their targets via the Fas-Fas ligand (FasL) signaling pathway, whereas $\mathrm{CD}^{+} \mathrm{T}$ cells kill target cells mainly by the perforin-mediated pathway, and only to a lesser extent by Fas-mediated mechanisms (14). FasL is a membrane protein, which induces apoptosis by binding to its receptor, Fas (CD95). Fas, a member of the TNF receptor family of proteins, requires cross-linking either with Fas antibodies or with cells expressing FasL to induce apoptosis (15). Since the FasFasL interaction is an induction pathway for apoptosis of vascular target cells, we hypothesized that the expression of FasL on graft-infiltrating cells might play an important role in the ef-

1. Abbreviations used in this paper: CyA, cyclosporine A; FasL, Fas ligand; PCNA, proliferating cell nuclear antigen; $Q_{\text {int }}$, quotient for the thickness of the intima; $Q_{\text {med }}$, quotient for the thickness of the media; SMC, smooth muscle cell; TUNEL, terminal transferase-mediated dUTP nick end labeling. 
fector phase of allograft vasculopathy. Thus, SMCs and endothelial cells expressing Fas may be targeted by activated and graft-infiltrating FasL-positive $\mathrm{T}$ cells and macrophages. Increased numbers of apoptotic cells have been observed previously in organ transplants undergoing chronic rejection $(16,17)$.

The primary aim of this study was to elucidate whether induction of tolerance protects against the development of chronic rejection and allograft vasculopathy. The fate of nonimmunosuppressed (control) aortic allografts was studied and compared with grafts given to operationally tolerant animals. To obtain information on contributing nonimmunologic factors, the grafts were subjected to a period of short $(1 \mathrm{~h})$ or long $(18 \mathrm{~h})$ cold ischemia before implantation. Syngeneic grafts and nontransplanted rat aortas served as further controls. $8 \mathrm{wk}$ after transplantation the histomorphology of the aortic allografts was analyzed quantitatively for intimal thickening, loss of medial cellularity, and adventitial inflammation. Mononuclear cell infiltrates were assessed for several $\mathrm{T}$ cell and macrophage markers. To gain further mechanistic insight into the development of lesions compatible with chronic rejection, the transplanted aortas were investigated for expression of Fas and FasL on vascular cells and on graft-infiltrating cells at the protein and mRNA levels. In addition, vascular cell death and/or nuclear damage were detected by in situ labeling of fragmented DNA using the in situ terminal transferase-mediated dUTP nick end labeling (TUNEL) method (18).

\section{Methods}

Animals and experimental design. Details of the operative procedures have been described elsewhere $(2,19)$. For allogeneic heart and aortic transplantations, $200-300-\mathrm{g}$ male PVG $\left(\mathrm{RT}^{\mathrm{c}}\right)$ and DA $\left(\mathrm{RT}^{\mathrm{a}}\right)$ rats (Møllegaard Farm, Skensved, Denmark) were used as donors and recipients, respectively. Heart grafts were transplanted heterotopically to the neck vessels of the recipients by using a nonsuture technique (20). The recipient rats were treated with cyclosporine A (CyA) (Sandoz AG, Basel, Switzerland) from days 0 to 30. CyA was mixed with Intralipid (Pharmacia and Upjohn, Stockholm, Sweden) and administered orally via a gastric feeding tube (model $\mathrm{CH} 05$; UnoPlast, Hundested, Denmark) at a daily dose of $15 \mathrm{mg} / \mathrm{kg}$, a dose that produced permanent cardiac graft acceptance. At day 100, the DA rats having beating cardiac allograft received a 10-15-mm long orthotopic aortic allograft from a PVG rat. Before aortic transplantation the grafts were incubated in a cold preservation solution (21) for either 1 or $18 \mathrm{~h}$. Controls consisted of allogeneic (PVG to DA) and syngeneic (PVG to PVG) aortic grafts without prior heart allografting and immunosuppression. To investigate the changes leading to transplant vasculopathy, the aortic allografts were explanted $8 \mathrm{wk}$ after the placement of the aorta. Each group consisted of at least six rats. In addition, nontolerant control allografts were removed at 2 or $24 \mathrm{~h}$, or 2,4 , or $8 \mathrm{wk}$ (at least three rats for each time point), and processed for the study of kinetics of apoptotic changes. The animal experimentation was approved by the local animal ethical committee, and handling of animals conformed with the National Institutes of Health Guidelines for the Care and Use of Laboratory Animals (22).

Tissue preparation. At the time of killing, the aortic grafts were divided into two parts; one was stored at $-70^{\circ} \mathrm{C}$ (approximately onethird of entire graft) and the other was fixed in $4 \%$ buffered formaldehyde and processed for embedment in paraffin (approximately two-thirds of entire graft). The latter was then divided into three segments.

Morphometrical quantification of vessel layers. Three 5- $\mu \mathrm{m}$ sections were taken from different levels of the paraffin-embedded grafts and evaluated for morphometry. The sections were stained with hematoxylin-eosin and analyzed blindly (by Levent M. Akyürek, Department of Pathology, University Hospital, Uppsala, Sweden) at a magnification of 20 using a conventional light microscope. A digitized image of the aorta was transferred to a screen. In each section, the areas within lumen, internal and external elastic lamina were circumscribed manually and measured. From these measurements, quotients for the thickness of the intima $\left(Q_{\text {int }}\right)$ and media $\left(Q_{\text {med }}\right)$ were calculated. $Q_{\text {int }}$ indicates the relative thickness (\%) of intima $\left[Q_{\text {int }}=\right.$ intima/(lumen + intima + media $) \times 100]$, and $Q_{\text {med }}$ indicates the relative thickness $(\%)$ of media $\left[Q_{\text {med }}=\right.$ media $/($ lumen + intima + media $) \times$ 100]. Therefore, a $Q_{\text {int }}$ value of $0 \%$ indicates no intimal thickening and a $Q_{\text {int }}$ value close to $100 \%$ indicates a total occlusion of the lumen by thickened intima. All image analysis processing was carried out on a color display monitor (model TFS6705KW-SG; Silicon Graphics Inc., Mountain View, CA) using the Silicon Graphics Computer Systems software (Silicon Graphics Inc.).

In situ TUNEL labeling. After deparaffinization, the slides were treated with proteinase K (Sigma Chemical Co., St. Louis, MO) (20 $\mathrm{mg} / \mathrm{ml}$ ) for $15 \mathrm{~min}$ at room temperature and washed in redistilled water four times for $2 \mathrm{~min}$. Slides were first incubated with $25 \mathrm{pmol}$ digoxigenin-11 dUTP and $5 \mathrm{U}$ of terminal transferase in a buffer consisting of $30 \mathrm{mM}$ Trizma base, $140 \mathrm{mM}$ sodium cacodylate, and $1 \mathrm{mM}$ cobalt chloride $\left(\mathrm{pH} \mathrm{7.2)}\right.$ for $3 \mathrm{~h}$ at $37^{\circ} \mathrm{C}$. Sections were then rinsed in a solution containing $300 \mathrm{mM}$ natrium chloride and $30 \mathrm{mM}$ natrium citrate $(\mathrm{pH} \mathrm{7.2)}$ for $15 \mathrm{~min}$, and washed in redistilled water for 9 min. Thereafter, sections were incubated with anti-digoxigenin antibody $(150 \mathrm{mU} / \mathrm{ml})$, conjugated with alkaline phosphatase for $30 \mathrm{~min}$ at room temperature, washed in a buffer $(100 \mathrm{mM}$ Trizma base, and 150 $\mathrm{mM}$ natrium chloride [ $\mathrm{pH} 7.5])$ for $20 \mathrm{~min}$ and equilibrated with another buffer (100 mM Trizma base, $100 \mathrm{mM}$ natrium chloride, and $50 \mathrm{mM}$ magnesium chloride [pH 9.5]) for at least $2 \mathrm{~min}$. The reaction product was visualized by means of a color solution (Boehringer Mannheim, Mannheim, Germany) containing 4-nitro blue tetrazolium chloride and $\mathrm{X}$-phosphate. The reaction was stopped by washing in a buffer containing $10 \mathrm{mM}$ Trizma base, and $10 \mathrm{mM}$ EDTA ( $\mathrm{pH} 8$ ). For negative controls, distilled water substituted for the TdT enzyme. Sections of bone marrow, in which cells are known to undergo apoptosis, were used as positive controls. The interpretation of TUNEL positivity was combined with the morphological analysis and Fas expression that is known to induce apoptosis upon binding to its ligand. The TUNEL technique is able to detect apoptosis characterized by cell shrinkage, pyknosis, budding, karyorrhexis, and apoptotic bodies by staining fragmented genomic DNA (18).

Quantification of number of apoptotic cells and adventitial cellularity. The number of apoptotic cells was quantified blindly by in situ TUNEL technique using morphometrical analysis. The sections were analyzed at a magnification of 20 using a conventional light microscope. Some reference pixels representative for positive in situ TUNEL-labeling were marked on a digitized image of the aortic graft sections. These reference pixels were manually counted on the screen in an area that was as large as the screen could provide (at least one third of the entire section). Separated reference pixels were considered as one apoptotic cell regardless of total numbers of pixels representing the apoptotic cell. At different time points medial cells were manually counted on the microphotographs of a high-power field $(\times 200)$ that covered approximately one-third of the entire allograft section. The percentage of TUNEL-positive medial cells was separately calculated by dividing the number of TUNEL-positive cells by the total number of cells obtained from graft sections stained with van Gieson. Final data were expressed as mean \pm SEM values.

Similarly, some reference pixels were marked for either nuclei of the cells or background in the adventitial layer that was separated from the intima and media on the screen. This analysis was performed on hematoxylin-eosin-stained sections. The ratio of the total number of pixels for nuclei to background resulted in the relative adventitial cellularity. Final results were given as mean \pm SEM values.

Collagen detection by Picrosirius staining. To investigate fibrotic changes of the aortic and heart transplants, Picrosirius red staining 
was applied in routine histopathology as described previously (23). Picrosirius red, a strong anionic acid dye, stains collagen by reacting, via its sulphonic acid groups, with basic groups present in the collagen molecule.

Primary antibodies. The polyclonal antibodies M-20 (1:100) and Q-20 (1:80) (Santa Cruz Biotechnology Inc., Santa Cruz, CA) were used against the Fas (24) and FasL (25) proteins, respectively. The mAbs W3/25 (1:1,200), which detects CD4 ${ }^{+}$cells, OX8 $(1: 1,000)$, which labels $\mathrm{CD}^{+} \mathrm{T}$ cells, ED1 $(1: 3,200)$, which recognizes monocyte-derived macrophages (Serotec Laboratory, Oxford, UK), smooth muscle-specific anti- $\alpha$ actin $(1: 1,400)$, which labels $\alpha$-actincontaining SMCs (Dakopatts Laboratory, Copenhagen, Denmark), and antiproliferating cell nuclear antigen (PCNA) (1:500; Dakopatts Laboratory [26]) were used as described previously (2). The last two antibodies were applied on formalin-fixed and paraffin-embedded tissue samples.

Immunohistochemistry. $5 \mu \mathrm{m}$ frozen midgraft sections of all aortic samples were fixed in $100 \%$ cold acetone, rinsed in PBS, and stained immunohistochemically as follows. Sections of the grafts were incubated at $4^{\circ} \mathrm{C}$ overnight with the primary antibody diluted in PBS containing $0.1 \%$ BSA. Biotinylated swine anti-rabbit Ig (1:80; Dakopatts Laboratory) or biotinylated rat-absorbed anti-mouse Ig (Vector Lab., Burlingame, CA) in PBS containing $0.1 \%$ BSA and $2 \%$ rat serum was subsequently applied. The avidin-biotin detection system was used (ABComplex/HRP; Dakopatts Laboratory). The reaction was visualized with 3,3'-diaminobenzidine and $0.03 \% \mathrm{H}_{2} \mathrm{O}_{2}$. Sections were lightly counterstained with Mayer's hematoxylin and mounted with cellulose triacetate (Coveraid; Sakura Finetechnical Co., Ltd., Tokyo, Japan).

An irrelevant antibody E11 (1:100) directed against the calcium binding receptor of human parathyroid cells (2) and omission of primary antibody served as negative controls. These control slides were invariably immunohistochemically negative. W3/25, OX8, and ED1 mAbs appropriately labeled control rat spleen sections, whereas PCNA properly recognized control human tonsil cells.

Combined immunohistochemistry and TUNEL. To investigate whether SMCs are apoptotic, the formalin-fixed paraffin-embedded sections were first stained with an antibody against the smooth muscle-specific $\alpha$-actin. The sections were rinsed with $0.1 \mathrm{~mol} / \mathrm{liter}$ of glycine- $\mathrm{HCl}$ buffer ( $\mathrm{pH} 2.2)$ for $60 \mathrm{~min}$ to remove unbound primary and secondary immune complexes. The apoptotic cells were then detected using in situ TUNEL technique on the same section. Counterstaining was performed with methyl green. Sections were also stained separately using single-label immunohistochemistry and in situ TUNEL. Staining pattern and intensity were found to be similar to that of the corresponding labeling in the double staining.

Immunohistological analysis. The number of positive cells in the intima, media, and adventitia was scored on a scale ranging from - to +++ where - indicates an absence of positively stained cells and +++ indicates a heavy infiltration of positive cells. This scoring scale is related to the number of positively stained cells and not to the staining intensity of the antigen expression by an individual cell. Evaluation was performed regardless of the thickness of the intima, media, and adventitia. Scoring was done by two investigators (Levent M. Akyürek [Department of Pathology, University Hospital, Uppsala, Sweden] and Cecilia Johnsson [Department of Transplantation Surgery, University Hospital, Uppsala, Sweden]), blinded to the experimental conditions. In the event of disagreement, the sections were reexamined until a common quantification was obtained. The final semiquantitative evaluation is presented (see Table I). The percentage of immunostained PCNA-positive cells was calculated by dividing the number of immunostained PCNA-positive cells by the total number of cells obtained from microphotographs of graft sections stained with van Gieson.

In situ hybridization for Fas $L m R N A$. Two aortic allografts from the tolerance-induced group and two allogeneic controls as well as a nontransplanted aortic segment were selected. Two 5- $\mu \mathrm{m}$, formalinfixed paraffin-embedded sections of each aortic sample were at- tached to slides (SuperFrost/Plus; Menzel-Gläser, Germany). RNA probes were synthesized on the basis of the published cDNA sequence of rat FasL (25). The in vitro transcription was performed using the DIG RNA labeling kit (Boehringer Mannheim) following the manufacturer's instructions. After linearization of the plasmid with HindIII, the antisense probe was transcribed in vitro by T3 RNA polymerase. The sense probe was transcribed by T7 RNA polymerase after linearization with ApaI. Sections were treated with proteinase $\mathrm{K}$ $(100 \mu \mathrm{g} / \mathrm{ml})$ and acetylated with 0.1 triethanolamine buffer $(\mathrm{pH} \mathrm{8.0)}$ containing $0.25 \%$ acetic anhydride (Sigma Chemical Co.). Slides were incubated with prehybridization buffer $(4 \times$ SSC containing $50 \%$ deionized formamide) for $30 \mathrm{~min}$. Hybridization was done with $0.5 \mu \mathrm{l}$ of the RNA transcription mixture of either the antisense or the sense probe in $30 \mu \mathrm{l}$ of hybridization buffer overnight at $55^{\circ} \mathrm{C}$. The hybridization buffer contained $2 \times$ SSC, $50 \%$ formamide, $10 \mathrm{mM}$ DDT, 1 $\mathrm{mg} / \mathrm{ml} \mathrm{tRNA}, 1 \mathrm{mg} / \mathrm{ml}$ sheared ssDNA, and $10 \mathrm{mg} / \mathrm{ml} \mathrm{BSA}$. Slides were briefly rinsed in $2 \times \mathrm{SSC}$, and washed in $0.2 \times \mathrm{SSC}$ twice for 30 min. After RNase treatment $(100 \mu \mathrm{g} / \mathrm{ml})$ for $30 \mathrm{~min}$ at $37^{\circ} \mathrm{C}$ the slides were washed and incubated with anti-digoxigenin AP (Boehringer Mannheim). Development was done with a substrate solution containing naphtol AS-MX phosphate, dimethylformamide, $0.1 \mathrm{M}$ Tris buffer, $1 \mathrm{M}$ levamisole, and fast-red salt as chromogen (Sigma Chemical Co.). The slides were finally counterstained with Mayer's hematoxylin and mounted.

Reverse transcription and PCR amplification. Frozen aortic grafts were used for total RNA isolation using the method of Chomczynski and Sacchi (27). The aortic tissues were homogenized with a Polytron tissue homogenizer (InterMed, Roskilde, Denmark). Individual grafts from allogeneic controls, tolerance-induced allografts, syngeneic control grafts, and nontransplanted abdominal aortas were pooled, three in each group, and total RNA was quantitated by spectrophotometry at $260 \mathrm{~nm}$. On the basis of the published cDNA sequence of rat FasL, the antisense (5' AAG CGA GGC GGC CTT NAG GGA G $3^{\prime}$ ) and the corresponding sense primer (5' GCA TCG CGC AGC TAT CGG AGA A 3') were designed for PCR (25). Glyceraldehyde-3-phosphate dehydrogenase (GAPDH), a housekeeping gene, served as a control. All reagents were obtained from Clontech Laboratory Inc. (Palo Alto, CA). Total RNA was incubated with $10 \mathrm{mM}$ of each dNTP, $10 \mathrm{U}$ Moloney murine leukemia virus reverse transcriptase, $20 \mathrm{U}$ RNasin, and $2 \mu \mathrm{M}$ oligo-dT in reverse transcriptase buffer and incubated at $42^{\circ} \mathrm{C}$ for $1 \mathrm{~h}$. After denaturation at $95^{\circ} \mathrm{C}$ for $5 \mathrm{~min}$, the synthesized cDNA was subjected to a 40 -cycle PCR, with an annealing temperature of $60^{\circ} \mathrm{C}$. The PCR mix contained $0.4 \mu \mathrm{M}$ of each primer, $200 \mu \mathrm{M}$ of each dNTP, $2 \mathrm{U}$ Taq polymerase in PCR buffer, and $2 \mathrm{mM} \mathrm{MgCl}$. All PCR products were run on a $1.5 \%$ agarose gel stained with ethidium bromide $(0.5 \mu \mathrm{g} / \mathrm{ml})$.

Statistical analysis. All statistical calculations were performed using the StatView ${ }^{\mathrm{TM}}$ program (Abacus Concepts, Inc., Berkeley, CA). ANOVA analyses of contingency tables were used for statistical comparisons between control and tolerance-induced aortic allografts, aortic layers (intima, media, and adventitia), and ischemia times ( 1 and $18 \mathrm{~h}$ ). If this test showed a significant heterogeneity of all groups, we further compared tolerance-induced aortic allografts with control allografts by applying the Bonferroni-Dunn test. Statistical significance was accepted at the $95 \%$ confidence level.

\section{Results}

Nonimmunosuppressed, nonpretreated animals receiving aortic allografts (control) with short $(1 \mathrm{~h})$ cold ischemia. The control aortic allografts showed advanced lesions of transplant arteriosclerosis, characterized by excessive intimal thickening, prominent loss of medial cellularity, disruption of internal elastic lamina, and heavy adventitial inflammatory reaction (Fig. 1) (see Fig. $3 A$ ). The intimal thickening consisted of intimal SMCs, monocyte-derived macrophages, and T cells (Table I). 

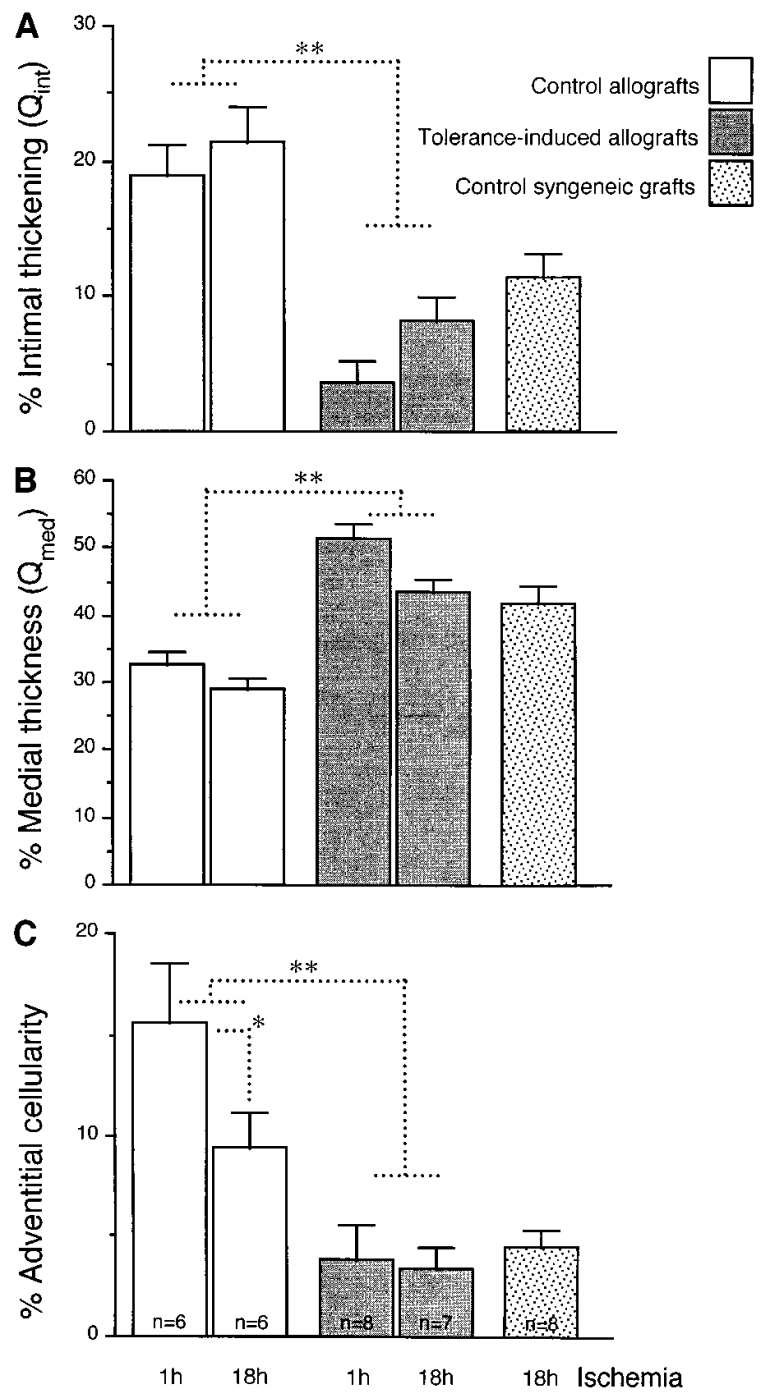

Figure 1. Parameters indicating the grade of allograft vasculopathy in the rat aortic transplants. Intimal thickening and medial thickness in aortic grafts are presented as quotients that indicate the relative thickness of aortic intimal $\left(Q_{\mathrm{int}}\right)(A)$ and medial $\left(Q_{\mathrm{med}}\right)(B)$ layers as described in Methods. Immune tolerance significantly improved all these parameters. There was significant intimal thickening and marked reduction in the medial layer of native aortic grafts. The number of adventitial cells significantly decreased in the toleranceinduced aortic allografts. Adventitial cellularity was contributed mainly by a heavy infiltration of mononuclear inflammatory cells $(C)$. Data are expressed as mean \pm SEM. $* P<0.05$ and $* * P<0.0001$ for native allografts versus tolerance-induced allografts. ANOVA was measured with a Bonferroni-Dunn test.

These control allografts contained 1,075 283 apoptotic cells per $\mathrm{mm}^{2}$ (Fig. 2), whereas a few single apoptotic endothelial cells were detected in nontransplanted normal aortas. Comparison of serial sections stained for T cells or monocytederived macrophages, and in situ TUNEL suggested that the main proportion of the apoptotic cells were graft-invading mononuclear cells. Also, some SMCs in the intima and media were apoptotic, which was confirmed by double-labeling with in situ TUNEL and smooth muscle anti- $\alpha$ actin antibody for SMCs (Fig. $3 C$ ).

Table I. Immunohistochemical Stainings of Aortic Grafts

\begin{tabular}{|c|c|c|c|c|}
\hline & Antibodies & $\begin{array}{c}\text { Control } \\
\text { allograft } \\
(n=8)\end{array}$ & $\begin{array}{l}\text { Tolerance- } \\
\text { induced } \\
\text { allografts } \\
(n=8)\end{array}$ & $\begin{array}{c}\text { Control } \\
\text { syngeneic } \\
\text { grafts } \\
(n=4)\end{array}$ \\
\hline \multirow[t]{5}{*}{ Intima } & M-20 (Fas) & $++/+++*$ & $+/++$ & ++ \\
\hline & Q-20 (FasL) & $+/++$ & $-1+$ & + \\
\hline & $\mathrm{W} 3 / 25\left(\mathrm{CD}^{+}{ }^{+}\right.$cells $)$ & ++ & $-/+$ & - \\
\hline & OX8 (CD8 ${ }^{+} \mathrm{T}$ cells $)$ & $+/++$ & $-/+$ & $-/+$ \\
\hline & ED1 (Mo/Mø) & $+/++$ & $-1+$ & - \\
\hline \multirow[t]{5}{*}{ Media } & M-20 (Fas) & ++ & $+/++$ & $+/++$ \\
\hline & Q-20 (FasL) & + & $-/+$ & $-/+$ \\
\hline & $\mathrm{W} 3 / 25\left(\mathrm{CD} 4^{+}\right.$cells $)$ & $+/++$ & $-/+$ & $-1+$ \\
\hline & OX8 (CD8 ${ }^{+} \mathrm{T}$ cells $)$ & $+/++$ & $-/+$ & - \\
\hline & ED1 (Mo/Mø) & $+/++$ & - & - \\
\hline \multirow[t]{5}{*}{ Adventitia } & M-20 (Fas) & $++/+++$ & $-/+$ & + \\
\hline & Q-20 (FasL) & $++/+++$ & $-/+$ & $-/+$ \\
\hline & $\mathrm{W} 3 / 25$ (CD4 $^{+}$cells $)$ & $++/+++$ & + & + \\
\hline & OX8 (CD8 ${ }^{+} \mathrm{T}$ cells $)$ & $+/++$ & $-1+$ & $-/+$ \\
\hline & ED1 (Mo/Mø) & ++ & $-1+$ & $-/+$ \\
\hline
\end{tabular}

*An arbitrary scale ranging between - and +++ was used blindly for the semiquantitative evaluation of immunoperoxidase staining. Note that an increased number of graft-infiltrating $\mathrm{T}$ cells and macrophages as well as Fas- and FasL-expressing cells in aortic control allografts compared with tolerance-induced allografts and syngeneic control grafts.

Fas and FasL protein (Fig. $4 C$ ) were strongly expressed in the areas of intimal and adventitial mononuclear inflammation of the control aortic allografts (Table I). Almost all apoptotic cells were located to the area of Fas expression. Staining of serial sections suggested the FasL-positive cells to be $\mathrm{CD}^{+} \mathrm{T}$ cells, CD8 ${ }^{+} \mathrm{T}$ cells, and monocyte-derived macrophages in the subendothelial and deep intimal thickening. Intimal SMCs, located adjacent to the vascular lumen in the neointima and medial SMCs, strongly expressed the Fas protein, whereas a weak FasL protein expression was simultaneously detected in serial sections of these grafts. Since there was a strong Fas protein expression in SMCs and endothelial cells, and induction of

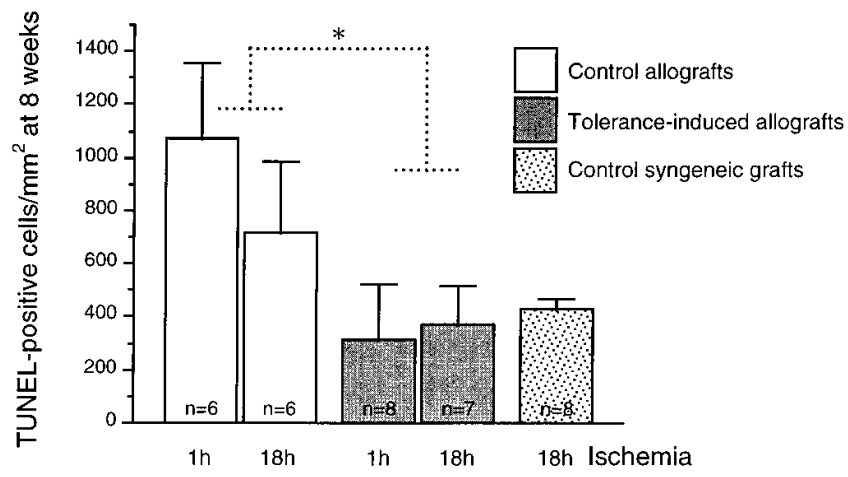

Figure 2. Apoptotic cell death in the entire aortic graft wall. Numbers of apoptotic cells detected by in situ TUNEL technique are fewer in the tolerance-induced aortic grafts when compared with control native allografts. Results are expressed as mean \pm SEM and compared by ANOVA. $* P<0.05$ for native versus tolerance-induced allografts. 


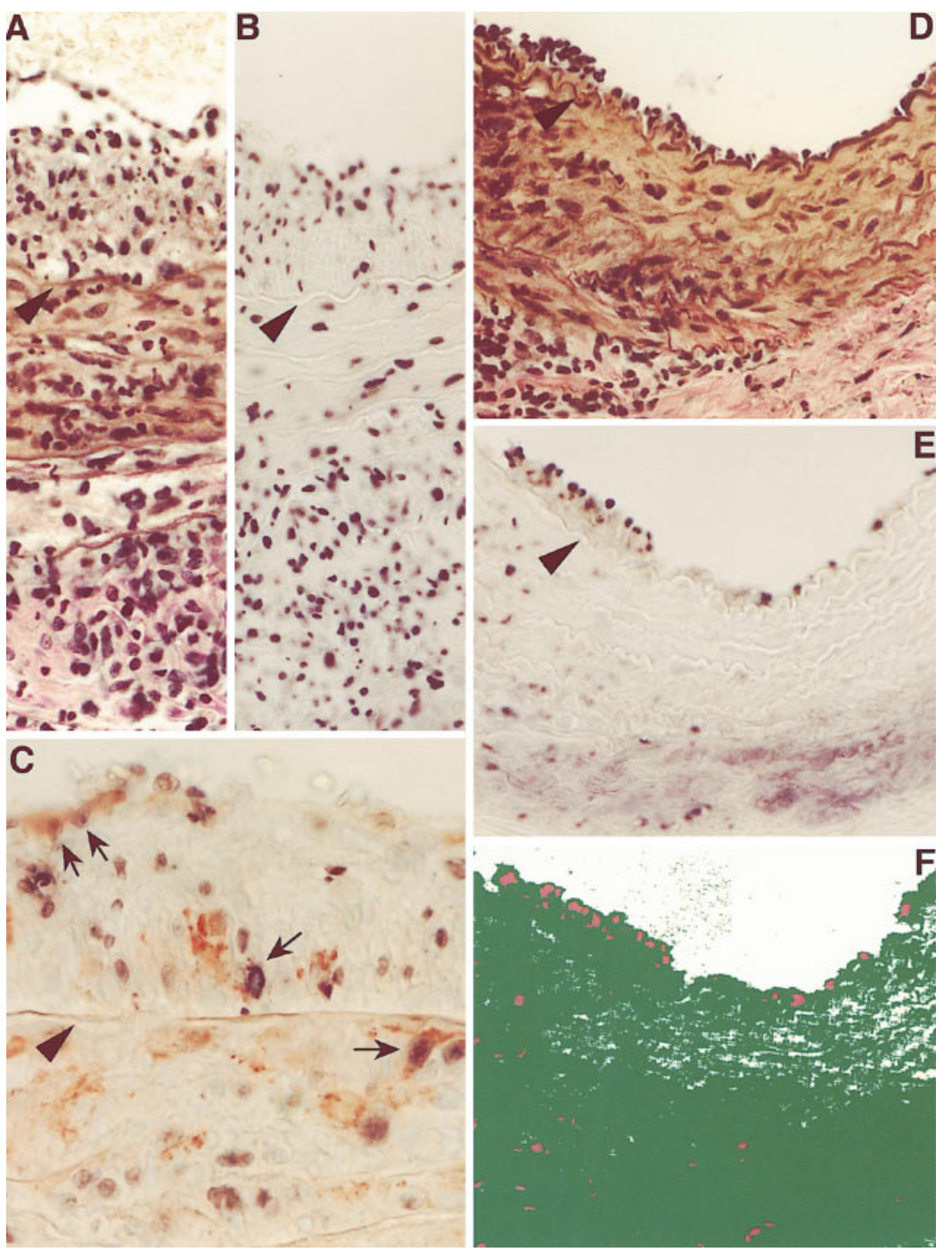

Figure 3. Comparison of histomorphological picture and in situ TUNEL positivity between native and tolerance-induced aortic allografts. Note an excessive intimal thickening, prominent loss of medial cellularity, and heavy medial and adventitial inflammatory infiltration $(A)$, as well as an increased number of apoptotic cells in a native aortic allograft $(B)$. Double labeling with in situ TUNEL and smooth muscle $\alpha$-actin antibody suggested that some of the apoptotic cells are SMCs in the intima and media. They are indicated by arrows $(C)$. In contrast to native allografts, there is less thickened neointima and an almost normal-appearing medial layer in a tolerance-induced aortic graft $(D)$. The same graft contains less apoptotic cells $(E)$ as quantified by image analysis. Red reference pixels represent TUNEL-positive apoptotic cells, whereas green pixels indicate background $(F)$. The arrowhead denotes the internal elastic lamina bordering the intimal and medial layers. Magnification, $200(A, B, D-F)$ and $400(C)$.

apoptosis in these cells requires cross-linking with cells expressing FasL, we have chosen FasL for further investigations at the mRNA level. Comparisons of serial sections, stained for cell type-specific markers, suggested that most FasL mRNA- expressing cells were $\mathrm{CD}^{+}$cells, $\mathrm{CD}^{+} \mathrm{T}$ cells, and monocytederived macrophages. However, some SMCs also expressed FasL protein and FasL mRNA.

Nonimmunosuppressed, nonpretreated animals receiving aor-

Figure 4. FasL mRNA expression in a native aortic allograft 8 wk after transplantation, revealed by in situ hybridization using digoxigeninlated riboprobes. Compare the histomorphology and in situ TUNEL-positivity from the same graft in Fig. 3, $A$ and $B$, respectively. Antisense hybridization shows labeling of neointimal cells and medial vascular cells $(A)$. Sense hybridization is negative $(B)$. Comparison of FasL mRNA expression with FasL protein expression in the same graft $(C)$. Arrowhead denotes internal elastic lamina bordering the intimal and medial layers. Magnification, 400. 


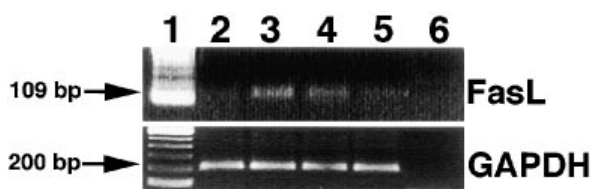

Figure 5. FasL mRNA expression revealed by reverse transcriptase PCR. All tissues were rapidly chilled and kept at $-70^{\circ} \mathrm{C}$. Ethidium bromide-stained $1.5 \%$ agarose electrophoresis gel. Lane 1 , DNA ladder; lane 2, nontransplanted abdominal aortas; lane 3, allograft controls; lane 4 , tolerance-induced allografts; lane 5 , syngeneic controls; and lane 6 , control with $\mathrm{dH}_{2} \mathrm{O}$.

tic allografts (control) with long $(18 \mathrm{~h})$ cold ischemia. In general, prolongation of the cold ischemia time of the aortic allografts did not alter the histomorphology of the grafts as compared with grafts with a short $(1 \mathrm{~h})$ cold ischemia time. However, adventitial cellular infiltrate was less prominent in the group with longer ischemia. Additionally, an increased collagen production, indicating fibrotic changes, was observed in the adventitial layer of these grafts when compared with the group with $1 \mathrm{~h}$ of ischemia. There were no differences between short and long ischemia times in Fas or FasL expression or the number of TUNEL-labeled cells. Neither were there any differences in the number of infiltrating $T$ cells and macrophages between grafts with short and long ischemia times in any layer of the aortic allograft wall, thus, these groups were combined and are presented together in Table I. A FasL mRNA band was clearly detectable in these allografts. Although the reverse transcriptase-PCR used in this study was not quantitative, FasL mRNA expression was strongest in the allograft controls (Fig. 5, lane 3) compared with tolerance-induced allografts (Fig. 5, lane 4), syngeneic controls (Fig. 5, lane 5), and nontransplanted aortas (Fig. 5, lane 2). The control housekeeping gene, glyceraldehyde-3-phosphate dehydrogenase (GAPDH), was expressed in all groups studied (Fig. 5).

Tolerant animals receiving aortic allografts with short $(1 \mathrm{~h})$ cold ischemia. Analysis of the aortic graft morphology revealed that tolerant animals displayed less intimal thickening (3.6 \pm 1.6 versus $19.0 \pm 2.3 \%, P<0.0001$ ) (Fig. 1) but a thicker medial layer (51.6 \pm 2.2 versus $32.8 \pm 1.8 \%, P<0.0001$ ) (Fig. 1 ) than the control allografts. The total number of medial cells was almost twofold greater than that found in the control allografts $(201 \pm 5$ versus $108 \pm 35, P<0.01)$. The number of infiltrating $\mathrm{T}$ cells and monocyte-derived macrophages in these grafts was considerably lower than in the control allografts. In fact, the pattern was comparable with that seen in the syngeneic aortic grafts (Table I). Also, the number of apoptotic cells was significantly lower in the tolerance-induced aortic grafts than in control allografts $(311 \pm 213$ versus $1,075 \pm 283$ cells per $\mathrm{mm}^{2}, P<0.05$ ) (Fig. 2). In addition, Fas and FasL protein expression was significantly lower after tolerance induction (Fig. 6, $A$ and $B$ ).

Tolerant animals receiving aortic allografts with long (18 h) cold ischemia. Prolonged cold ischemic time yielded only minor changes of graft morphology, with one important exception, that of intimal thickening. Thus, the intima was thicker in grafts subjected to $18 \mathrm{~h}$ of ischemia than in those with an ischemic time of $1 \mathrm{~h}(8.2 \pm 1.8$ versus $3.6 \pm 1.6 \%)$. The findings were similar to what was observed in syngeneic grafts (see below). It is important to note that the inflammatory cell inva- sion was of the same minimal character as that of tolerant animals with a short cold ischemia time.

Graft morphology of the cardiac allograft used to induce tolerance. Comparison of cardiac allografts with nontransplanted normal hearts by Picrosirius red staining, a marker of fibrotic changes and collagen production, indicated increased fibrotic changes in the myocardium and coronary vessel wall. Histological examinations of hematoxylin-eosin-stained sections of the transplanted hearts, explanted $160 \mathrm{~d}$ after transplantation, did not show proliferative vascular changes in the majority of the coronary vessels. However, endotheliitis and focal invasion of inflammatory cells in the medial layer was occasionally seen. In the myocardium, focal mild inflammatory infiltrates consisting of mononuclear cells could be observed. A slight endocarditis was seen in some cases.

Syngeneic aortic grafts. In syngeneic grafts, prolonged cold ischemia time $(18 \mathrm{~h})$ resulted in an intimal thickening comparable with that seen in the tolerance-induced aortic allografts (11.3 \pm 1.8 versus $8.2 \pm 1.8 \%$ ) (Fig. 1$)$. The number of adventitial inflammatory cells, in situ TUNEL-positive apoptotic cells (Fig. 2), and cells expressing Fas or FasL (Table I) were similar in the syngeneic and the tolerance-induced allogeneic group. Thus, the relative adventitial cellularity was $4.5 \pm 0.9 \%$ in syngeneic grafts and $3.4 \pm 1.1 \%$ in tolerance-induced allografts (Fig. 1) and the number of in situ TUNEL-positive apoptotic cells was $433 \pm 40$ and $368 \pm 150$, respectively (Fig. 2).

Kinetics of apoptosis during the development of allograft arteriosclerosis. This part of the study was performed in nontolerant control aortic allografts with $1 \mathrm{~h}$ of cold ischemia at different time points ( $2 \mathrm{~h}$ to $8 \mathrm{wk}$ ). Apoptotic endothelial cells were observed as early as $2 \mathrm{~h}$ after allograft transplantation, and $8 \mathrm{wk}$ after transplantation almost $50 \%$ of the intimal cells were apoptotic $(49.0 \pm 7.0 \%)$ (Fig. $7, A-H)$. At this time point $13.8 \pm 3.7 \%$ of the intimal cells were proliferating (i.e., PCNApositive) (Fig. 7 I). In the medial layer, the proportion of apoptotic cells increased in the early posttransplantation period, reaching a peak after 2 wk when $93.7 \pm 6.2 \%$ of the cells were TUNEL-positive (Fig. 8). However, the medial cellularity was reduced over this time period (Fig. 7, $B, D$, and $F$ ), and at the late stage of allograft vasculopathy only a few medial SMCs were viable (Fig. 7, $G$ and $H$ ). At all time points studied ( $2 \mathrm{~h}$ to 8 wk after transplantation) medial PCNA-positive (by morphology) SMCs were observed in the allografts. At least every 10th medial cell was PCNA-positive. After 4 wk a heavy infiltration of mononuclear inflammatory cells was observed in the medial layer. These cells contributed to the increased medial cellularity as well as to the increased numbers of apoptotic and proliferating cells (Fig. 7, $G-I$ ).

\section{Discussion}

The main finding in this work was the evidence of ameliorated allograft vasculopathy by induction of immune tolerance. The tolerance induction through heart allografting and temporary immunosuppression largely prevented persistent mononuclear cell infiltrates of subsequent aortic allografts. Prolonged exposure to ischemia ( $18 \mathrm{~h}$ instead of $1 \mathrm{~h}$ ) did not alter the inflammatory pattern in the aortic grafts of the tolerant animals.

Although the underlying mechanisms associated with tolerance induction are not completely clear, antigen-specific suppressor T cell development (28) and functional clonal deletion (29) may both have an impact on this process. Experimentally, 

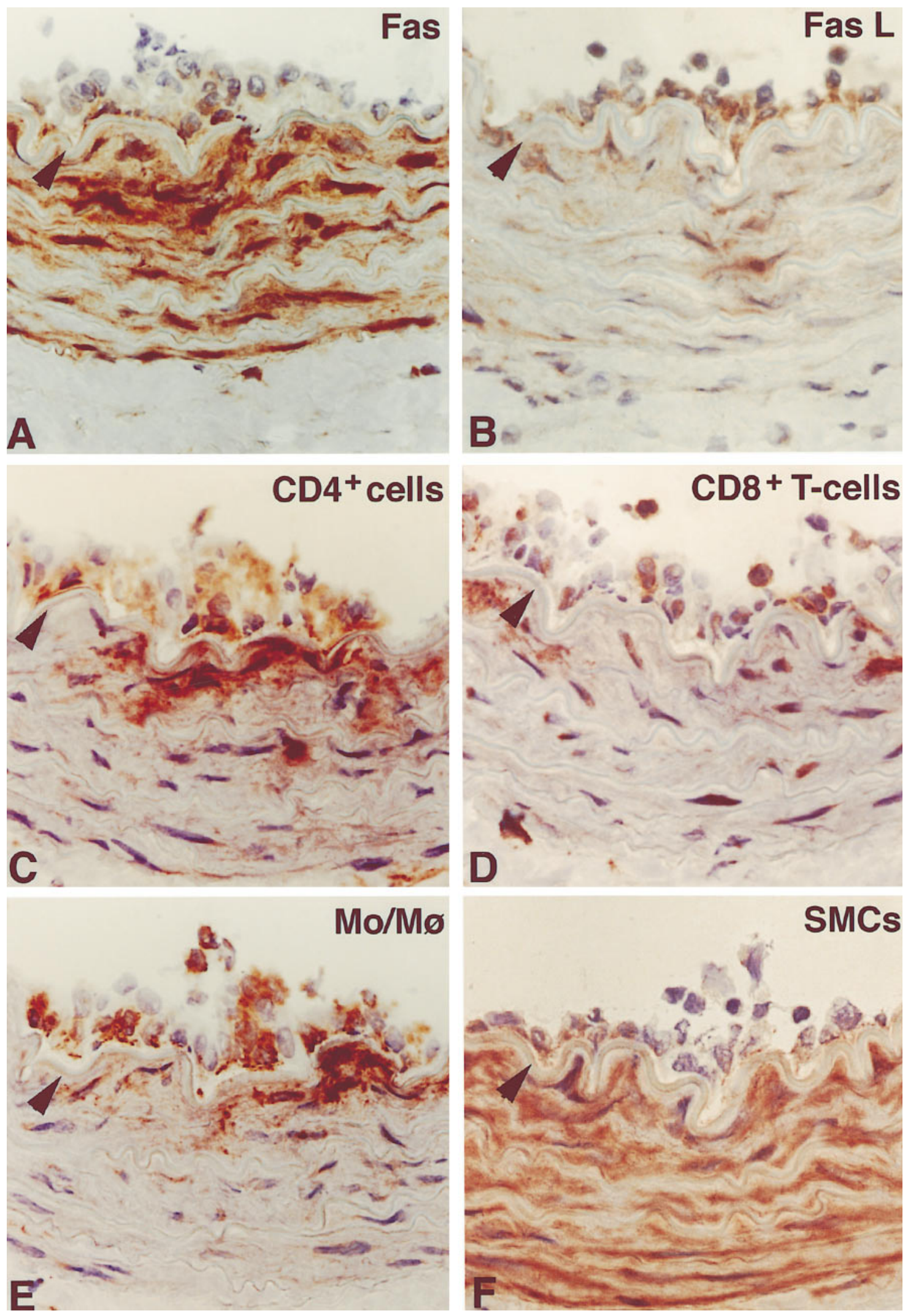

Figure 6. Serial immunohistochemical staining of a tolerance-induced rat aortic allograft for the localization of Fas $(A)$ and FasL $(B)$ expression 8 wk after transplantation. Fas is expressed mainly by $\mathrm{CD}^{+}(C)$ and $\mathrm{CD}^{+}(D) \mathrm{T}$ cells, monocyte-derived macrophages $(\mathrm{Mo} / \mathrm{M} \varnothing)(E)$, and $\mathrm{SMCs}$ $(F)$, whereas a strong FasL expression is shown by $\mathrm{CD} 4^{+}$and $\mathrm{CD} 8^{+} \mathrm{T}$ cells, and monocyte-derived macrophages. Arrowhead denotes internal elastic lamina bordering the intimal and medial layers. Immunoperoxidase staining was counterstained with Mayer's hematoxylin. Magnification, 400 . 

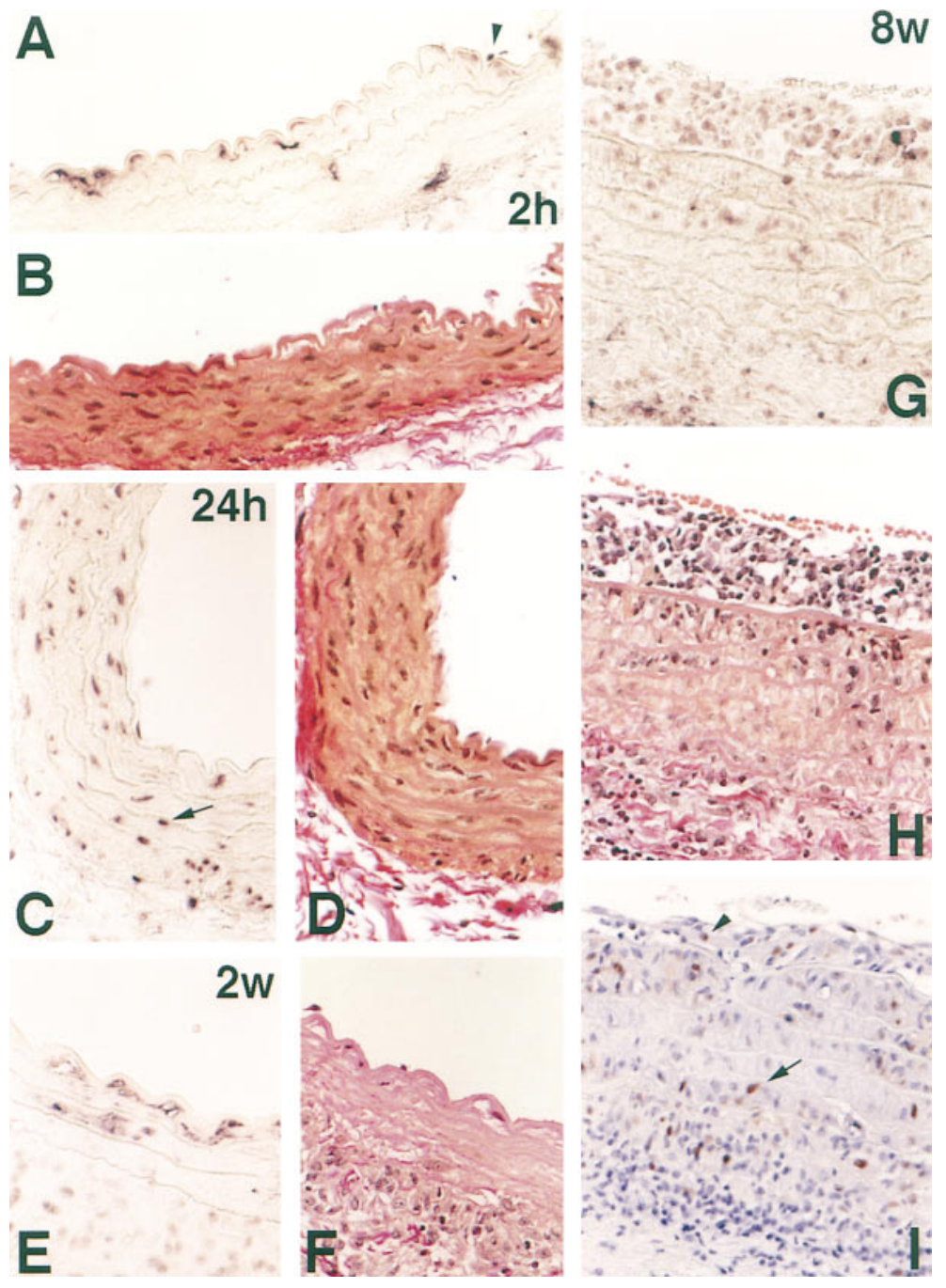

Figure 7. Kinetics of apoptosis in the allograft vessel wall during the development of chronic rejection. Control allografts were explanted 2 and $24 \mathrm{~h}$, and 2 and $8 \mathrm{wk}$ after transplantation. The numbers of TUNEL-positive apoptotic cells $(A, C, E$, and $G)$ are compared with the total numbers of cells in respective graft sections stained with van Gieson $(B, D, F$, and $H)$. Note the decreased medial cellularity and increased neointima formation over time. The number of PCNA-positive replicating cells $(I)$ is also compared with the number of TUNEL-positive apoptotic cells $(G)$ and the total cell number $(H)$ in serial sections of a control allograft 8 wk after transplantation. Arrowhead indicates an apoptotic intimal cell in $A$ and a proliferating neointimal cell in $I$. Arrow indicates an apoptotic medial cell in $C$ and a proliferating medial cell in $I$. Magnification, 200.

acute rejection of islet cell, kidney, and small bowel allografts have been prevented by various tolerance induction protocols (30-32). However, the impact on chronic rejection and transplant vasculopathy has not been specifically investigated in a quantitative fashion. Tolerance induction by hematopoietic chimerism is a promising approach both in preventing chronic rejection and in avoiding long-term maintenance immunosuppression (4). However, our study shows that it may not be necessary to use such extensive measures to modulate the immune response. Instead it may be sufficient to use appropriate immunosuppression and antigen exposure to achieve suitable circumstances for graft acceptance and attenuation of chronic rejection. In this experimental setting it was sufficient to use CyA for immunosuppression, but in a human setting other immunosuppressive protocols may be needed. The type of antigen exposure may also be critical. Thus, blood transfusions, sufficient to prevent acute rejection, did not prevent future chronic rejection (8).

The contribution of several nonimmunologic factors, like cold ischemia, to the development of chronic rejection is debated (33). In our study, tolerance induction prevented persistent mononuclear cell infiltrates. Thus, the tolerance-induced allografts resembled syngeneic grafts in the sense that both contained significantly fewer $\mathrm{T}$ cells and macrophages than aortic allograft controls. Our finding argues against two hypotheses that have been previously put forward: that ischemia, per se, induces inflammation and that ischemia acts in synergy with immunological factors to aggravate chronic rejection. At least when prolonged ischemia is used as a prototype for nonimmunologic factors, additive effects of immunological and nonimmunological causes could not be observed. Instead, an apparent noninflammatory neointimal thickening was observed. We therefore conclude that the immunologic and nonimmunologic contributions to chronic rejection lesions are separate phenomena, although a transient inflammation in the ischemic grafts could not be excluded with this study protocol. We actually observed a reduced adventitial inflammation in control aortic allografts subjected to prolonged ischemia. However, we do not interpret this result to suggest that prolonged cold ischemia is protective. On the contrary, the advanced adventitial fibrosis observed in these grafts may reflect a more rapid destructive process of the adventitia.

The experimental design of this study also provided ideal circumstances for further analysis of the nature of the immunologic damage occurring in control allografts. The clear-cut morphologic differences between aortic grafts of nontolerant 


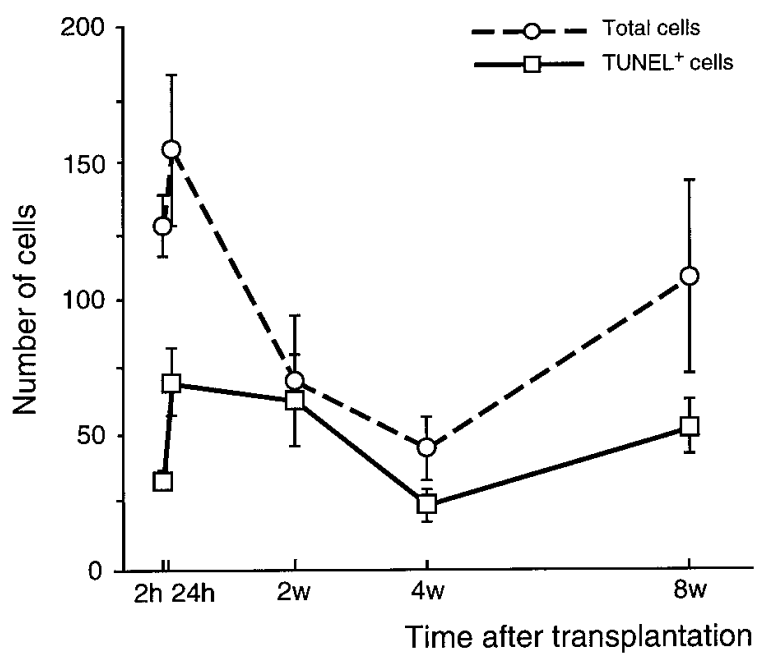

Figure 8. Kinetics of medial cellularity and apoptotic cells in nontolerant control aortic allografts. The control allografts were removed 2 $(n=3)$ and $24(n=4) \mathrm{h}$, and $2(n=3), 4(n=4)$, and $8(n=3)$ wk after transplantation. The total number of medial cells (circles) in graft sections stained with van Gieson was manually counted in a section that covered approximately one-third of the circumference of the entire allograft section as described in Methods. The number of TUNEL-positive medial cells (squares) was counted in a similar way in parallel sections. Data are expressed as mean \pm SEM.

and tolerant animals prompted us to use new investigative tools to identify possible mechanisms of graft destruction. Further observations suggested that the increased vascular changes in the control allografts may be partly attributed to an interference with the Fas-FasL- signaling pathway. Mononuclear inflammatory cells may interact with vascular endothelium and SMCs in a paracrine fashion in the aortic allograft wall, inducing apoptosis of the latter. Fas-mediated apoptosis may also be induced within the mononuclear cell population and the SMC population separately. We and others have reported previously that myocyte proliferation, most likely driven by growth factors, is a key element in the aorta allograft model and in other situations of chronic graft rejection (3436). In this study we also observed PCNA-positive cells (most likely at least partly SMCs) in the media of nontolerant allografts 2 wk after transplantation. At this time the degree of apoptosis, as detected by the TUNEL technique, was extremely high. The phenomenon seemed to persist, since large amounts of PCNA- and TUNEL-positive cells were found also 8 wk after transplantation. Simultaneous occurrence of apoptosis and proliferation of SMCs may explain, particularly well, the nature of the chronic rejection process, with emphasis on chronic. Thus, we have two actively counteracting mechanisms occurring at the same time with $\mathrm{CD}^{+}$cells presumably mediating apoptosis via the Fas-FasL system and a simultaneous SMC proliferation. In support of this view, myocyte necrosis was reported recently during the pathogenesis of proliferative arterial vasculopathy $(37,38)$. Our in vivo data suggest that rat aortic SMCs overexpress Fas during alloimmune reactions. This increase in Fas expression may lead to significant apoptosis of myocytes.

Studies in models of arterial injury have demonstrated apoptotic changes in the vessel wall within a few hours of injury (39,
40), something that we verify here also in the aortic allograft model where we observed TUNEL-positive cells already $2 \mathrm{~h}$ upon revascularization. 2 wk after transplantation, the medial layer was almost acellular, a typical feature of allograft vasculopathy. Therefore, the proliferative properties of a few residing vital SMCs and/or new vascular SMCs replaced by host cells may be important for sustained graft integrity after this time point (41).

Apoptosis of cultured vascular SMCs is regulated, at least in part, by protein kinases $\mathrm{C}$ and $\mathrm{A}$, which are regulated by antiapoptotic protooncogene Bcl-2 expression (42). Simultaneous exposure to TNF- $\alpha$, IL-1, and IFN- $\gamma$ promotes apoptosis of cultured vascular SMCs (43). These proinflammatory cytokines are certainly involved in the initiation and progression of transplant vasculopathy (35). In vitro, nitric oxide is also reported to induce upregulation of Fas expression and apoptosis in SMCs via a cGMP-independent mechanism (37). Growth factors, such as PDGF, bFGF, and IGF-1, which have been demonstrated in aortic allografts, not only promote cell proliferation and growth but are also known to counteract apoptosis (44). Thus, a situation may be at hand, where SMCs in the vascular wall are subjected to induction of apoptosis and counteracted by growth factors that also stimulate migration and proliferation of SMCs. It is well known that within cells, arteriosclerosis-like changes interact in a complex way during the development of allograft vasculopathy. Factors produced by arterial wall cells can stimulate neighboring cells in a paracrine, or themselves in an autocrine fashion. We have previously shown an induced expression of TGF- $\beta$ family $(36,45)$ and nitric oxide synthase isoforms (46) by allogeneic as well as ischemic stimuli. Both molecules directly contribute to neointimal lesion formation $(47,48)$ and have also been shown to mediate apoptosis in vascular endothelial cells, SMCs, and macrophages in other models $(37,49-51)$. In contrast, other proinflammatory mediators such as TNF- $\alpha$ and LPS, and cytokines including GM-CSF, IL-4, and IFN- $\gamma$, have been shown to prevent spontaneous apoptosis, but had no effect on the expression of Fas or FasL in human monocytes and macrophages (52). In the late stage of allograft vasculopathy, many of the infiltrating $\mathrm{T}$ cells and macrophages in the neointima and adventitia were apoptotic. They may, by then, have reached their target and destroyed vascular cells. As a consequence, they either have to leave the tissue or die. Since there is ever increasing evidence from the literature that several factors such as perforin, TNF- $\alpha, c-m y c$, $\mathrm{p} 53$, proteases related to IL- $1 \beta$ converting enzyme, and BclXs act as mediators of apoptosis (53), it is most likely that there is a complex system involved in the regulation of apoptosis where the Fas-FasL interaction is one of the critical modes for the $\mathrm{CD}^{+}$cell-mediated immune system to damage the SMCs.

In summary, this study shows that the development of transplant arteriosclerosis in an in vivo model of chronic aortic allograft rejection can be ameliorated by a mechanism of tolerance induction. The beneficial effect of tolerance is not abrogated by prolonged cold ischemia. Cold ischemia has such results in intimal thickening irrespective of the immune status of the recipient, thus, both tolerant and syngeneic recipients display similar changes. Control allografts express the Fas-FasL membrane proteins in vascular SMCs, endothelial cells, and graft infiltrating mononuclear cells to a much higher degree than grafts from tolerant animals, implying that SMC necrosis and endothelial disruption, which are common in vessel wall 
remodeling in chronic rejection, are caused by immune reactions.

\section{Acknowledgments}

The authors would like to acknowledge the skilled technical assistance of Ulla Svensson and Therése Johansson. We are also gratefully indebted to Dr. Shigekazu Nagata (Department of Genetics, Osaka University Medical School, Osaka, Japan) for providing FasL cDNA.

The research work was supported by the Swedish Medical Research Council (grants 17x-07172, 19x-09110, and 12XS-12710-01A), the Swedish Heart and Lung Foundation, the Baxter Extramural Grant Programme, Njursjukas Förening i CUWX-länen, the Uppsala County Association Against Heart and Lung Diseases, the Leopoldina/BMBF, and the Foundation of the René Touraine Paris.

\section{References}

1. Fellström, B.C., and E. Larsson. 1993. Pathogenesis and treatment perspectives of chronic graft rejection (CVR). Immunol. Rev. 134:83-98.

2. Wanders, A., M.L. Akyürek, J. Waltenberger, Z.P. Ren, C. Stafberg, K. Funa, E. Larsson, and B. Fellström. 1995. Ischemia-induced transplant arteriosclerosis in the rat. Arterioscler. Thromb. Vasc. Biol. 15:145-155.

3. Orloff, M.S., E.M. DeMara, M.L. Coppage, N. Leong, M.A. Fallon, J. Sickel, X.J. Zuo, J. Prehn, and S.C. Jordan. 1995. Prevention of chronic rejection and graft arteriosclerosis by tolerance induction. Transplantation. 59:282-288.

4. Blom, D., N.J. Morrissey, C. Mesonero, M. Coppage, T. Fisher, X.J. Zuo, S.C. Jordan, and M.S. Orloff. 1996. Induction of specific tolerance through mixed hematopoietic chimerism prevents chronic renal allograft rejection in a rat model. Surgery. 120:219-220.

5. Claesson, K., P. Larsson, R. Holmdahl, L. Klareskog, U. Forsum, and G. Tufveson. 1987. Positive effects of anti-T-cell monoclonal antibodies on rat allograft. Transplant. Proc. 19:615-616.

6. Shirwan, H., H.K. Wang, L. Barwari, L. Makowka, and D.V. Cramer. 1996. Pretransplant injection of allograft recipients with donor blood or lymphocytes permits allograft tolerance without the presence of persistent donor microchimerism. Transplantation. 61:1382-1386.

7. Räisenen-Sokolowski, A., S. Yilmaz, T. Paavonen, M.J. Tikkanen, and P. Häyry. 1994. Partial inhibiton of allograft arteriosclerosis (chronic rejection) by 15-deoxyspergualin. Transplantation. 57:1772-1777.

8. Hewith C.W., K.S. Black, J.C. Harman, K.R. Beko II, H.S. Lee, A.P. Patel, and D.C. Martin. 1990. Partial tolerance in rat renal allograft recipients following multiple blood transfusions and concomitant cyclosporine. Transplantation. 49:194-198.

9. Stein-Oakley, A.N., P. Jablonski, A. Tzanidis, K. Baxter, B.O. Howden, V.C. Marshall, and N.M. Thomson. 1993. Development of chronic injury and nature of interstitial infiltrate in a model of chronic renal allograft rejection. Transplantation. 56:1299-1305.

10. Zhang, H., L. Horwitz, P. Ruvolo, P. Colombani, and A.D. Hess. 1995. The role of cyclosporine-induced autoreactive T lymphocytes in solid organ allograft survival and chronic rejection. Transplantation. 60:115-122.

11. Jablonski, P., K. Baxter, B.O. Howden, A.C. Thomas, V.C. Marshall, A. Stein-Oakley, and N.M. Thomson. 1995. A reproducible model of chronic rejection in rat renal allografts. Aust. NZ. J. Surg. 65:114-119.

12. Sayegh, M.H., and C.B. Carpenter. 1996. Role of indirect allorecognition in allograft rejection. Int. Rev. Immunol. 13:221-229.

13. Akyürek, M.L. 1996. Transplant arteriosclerosis. Experimental studies in the rat. Comprehensive Summaries of Uppsala Dissertations from the Faculty of Medicine. Acta Universitatis Upsaliensis. 654:24-27.

14. Dong, C., J.E. Wilson, G.L. Winters, and B.M. McManus. 1996. Human transplant coronary artery disease: pathological evidence for Fas-mediated apoptotic cytotoxicity in allograft vasculopathy. Lab. Invest. 74:921-931.

15. Suda, T., and S. Nagata. 1994. Purification and characterization of the Fas-ligand that induces apoptosis. J. Exp. Med. 179:873-879.

16. Laine, J., P. Etelämäki, C. Holmberg, and L. Dunkel. 1997. Apoptotic cell death in human chronic renal allograft rejection. Transplantation. 63:101-105.

17. Bergese, S.D., S.M. Klenotic, M.E. Wakely, D.D. Sedmak, and C.G. Orosz. 1997. Apoptosis in murine cardiac grafts. Transplantation. 63:320-325.

18. Gavrieli, Y., Y. Sherman, and S.A. Ben-Sasson. 1992. Identification of programmed cell death in situ via specific labeling of nuclear DNA fragmentation. J. Cell Biol. 119:493-501.

19. Johnsson, C., and G. Tufveson. 1994. MC 1288-a vitamin D analogue with immunosuppressive effects on heart and small bowel grafts. Transplant. Int. 7:392-397.

20. Olausson, M., L. Mjörnstedt, L. Lindholm, and H. Brynger. 1984. Nonsuture organ grafting to the neck vessels in the rat. Acta Chir. Scand. 150:463-467.

21. Jacobsson, J., J. Wahlberg, L. Frödin, B. Odlin, and G. Tufveson. 1989.
Organ flush out solutions and cold storage preservation solutions: effect on organ cooling and post-ischemic erythrocyte trapping in kidney grafts. Scand. J. Urol. Nephrol. 32:219-222.

22. Institute of Laboratory Animal Resources. Committee on Care and Use of Laboratory Animals. 1985. Guide for the Care and Use of Laboratory Animals. U.S. Department of Health, Public Health Service, National Institutes of Health. Bethesda, MD. 86-123.

23. DeLellis, R.L., and M.C. Bowling. 1970. The use of Sirius red and Congo red staining in routine histopathology. Hum. Pathol. 1:655.

24. Drappa, J., N. Brot, and K.B. Elkon. 1993. The Fas protein is expressed at high levels on CD4+CD8+ thymocytes and activated mature lymphocytes in normal mice but not in the lupus-prone strain, MRL lpr/lpr. Proc. Natl. Acad. Sci. USA. 90:10340-10344.

25. Suda, T., T. Takahashi, P. Golstein, and S. Nagata. 1993. Molecular cloning and expression of the Fas ligand, a novel member of the tumor necrosis factor family. Cell. 75:1169-1178

26. Waseem, N.H., and D.P. Lane. 1990. Monoclonal antibody analysis of the proliferating cell nuclear antigen (PCNA). Structural conservation and the detection of a nucleolar form. J. Cell. Sci. 96:121-129.

27. Chomczynski, P., and N. Sacchi. 1987. Single-step method of RNA isolation by acid guanidium thiocyanate-phenol chloroform extraction. Anal. Biochem. 162:156-160.

28. Yoshimura, N., and B.H. Kahan. 1985. Induction of T suppressor cells by extracted histocompatibilty antigen combined with cyclosporine. Transplant. Proc. 17:1341.

29. Ito, T., S. Stepkowski, and B.D. Kahan. 1988. Frequency of T cytotoxic cells after perioperative treatment with extracted antigen and cyclosporine in rat cardiac transplantation. Transplant. Proc. 20:1045-1052.

30. Posselt, A.M., C.F. Barker, J.E. Tomaszewski, J.F. Markmann, M.A. Choti, and A. Naji. 1990. Induction of donor-specific unresponsiveness by intrathymic islet. Science. 249:1293-1295.

31. Remuzzi, G., and N. Perico. 1991. Induction of unresponsiveness via intrathymic inoculation. Lancet. 338:1487-1488.

32. Chowdhury, N.C., R.A. Fawwaz, and S.F. Oluwole. 1993. Induction of donor-specific tolerance to rat cardiac and small bowel. J. Surg. Res. 54:368-374.

33. Fellström, B.C., M.L. Akyürek, E.M. Dimény, M. Kaijser, E. Larsson, A. Wanders, and J. Wahlberg. 1996. Nonimmunological factors involved in long-term allograft deterioration. Adv. Nephrol. Necker Hosp. 25:51-62.

34. Rubin, K., A. Tingström, G.K. Hansson, E. Larsson, L. Rönnstrand, L. Klareskog, L. Claesson-Welsh, C.-H. Heldin, and B. Fellström. 1988. Induction of B-type receptors for platelet-derived growth factor in vascular inflammation: possible implication for development of vascular proliferative lesions. Lancet. 1:1099-1102.

35. Paul, L.C. 1995. Chronic renal transplant loss. Kidney Int. 36:1491-1499.

36. Waltenberger, J., M.L. Akyürek, M. Aurivillius, A. Wanders, E. Larsson, B.C. Fellström, and K. Funa. 1996. Ischemia-induced transplant arteriosclerosis in the rat. Induction of peptide growth factor expression. Arterioscler. Thromb. Vasc. Biol. 16:1516-1523.

37. Fukuo, K., S. Hata, T. Suhara, T. Nakahashi, Y. Shinto, Y. Tsujimoto, S. Morimoto, and T. Ogihara. 1996. Nitric oxide induces upregulation of Fas and apoptosis in vascular smooth muscle. Hypertension. 27:823-826.

38. Geng, Y.-G., L.E. Henderson, E.B. Levesque, M. Muszynski, and P. Libby. 1997. Fas is expressed in human atherosclerotic intima and promotes apoptosis of cytokine-primed human vascular smooth muscle cells. Arterioscler. Thromb. Vasc. Biol. 17:2200-2208.

39. Bochaton-Piallat, M., P. Ropraz, F. Gabbiani, and G. Gabbiani. 1996. Phenotypic heterogeneity of rat arterial smooth muscle cell clones. Implications for the development of experimental intimal thickening. Arterioscler. Thromb. Vasc. Biol. 16:815-820.

40. Perlman, H., L. Maillard, K. Krasinski, and K. Walsh. 1997. Evidence for the rapid onset of apoptosis in medial smooth muscle cells after balloon injury. Circulation. 95:981-987.

41. Mennander, A., S. Tiisala, J. Halttunen, S. Yilmaz, T. Paavonen, and P. Häyry. 1991. Chronic rejection in rat aortic allografts. An experimental model for transplant arteriosclerosis. Arterioscler. Thromb. 11:671-680.

42. Leszczynski, D., Y. Zhao, M. Luokkamäki, and M.L. Foegh. 1994. Apoptosis of vascular smooth muscle cells. Protein kinase $\mathrm{C}$ and oncoprotein Bcl-2 are involved in regulation of apoptosis in nontransformed rat vascular smooth muscle cells. Am. J. Pathol. 145:1265-1270

43. Geng, Y.-G., Q. Wu, M. Muszynski, G.K. Hansson, and P. Libby. 1996 Apoptosis of vascular smooth muscle cells induced by in vitro stimulation with interferon- $\gamma$, tumor necrosis factor- $\alpha$, and interleukin-1 $\beta$. Arterioscler. Thromb. Vasc. Biol. 16:19-27.

44. Bennett, M.R., G.I. Evan, and S.M. Schwartz. 1995. Apoptosis of human vascular smooth muscle cells derived from normal vessels and coronary atherosclerotic plaques. J. Clin. Invest. 95:2266-2274.

45. Lantz, I., E. Dimény, E. Larsson, B. Fellström, and K. Funa. 1996. Increased immunoreactivity of transforming growth factor- $\beta$ in kidney transplants. Transplant. Immunol. 4:209-214.

46. Akyürek, L.M., B.C. Fellström, Z.Q. Yan, G.K. Hansson, K. Funa, and E. Larsson. 1996. Inducible and endothelial nitric oxide synthase expression during development of transplant arteriosclerosis. Am. J. Pathol. 149:1981- 
1990.

47. Nabel, E.G., L. Shum, V.J. Pompili, Z.Y. Yang, H. San, H.B. Shu, S. Liptay, L. Gold, D. Gordon, R. Derynck, et al. 1993. Direct transfer of transforming growth factor $\beta 1$ gene into arteries stimulates fibrocellular hyperplasia. Proc. Natl. Acad. Sci. USA. 90:10759-10763.

48. Shears, L.L., N. Kawaharada, E. Tzeng, T.R. Billiar, S.C. Watkins, I. Kovesdi, A. Lizonova, and S.M. Pham. 1997. Inducible nitric oxide synthase suppresses the development of allograft arteriosclerosis. J. Clin. Invest. 100: 2035-2042.

49. Nishio, E., K. Fukushima, M. Shiozaki, and Y. Watanabe. 1996. Nitric oxide donor SNAP induces apoptosis in smooth muscle cells through cGMPindependent mechanism. Biochem. Biophys. Res. Commun. 221:163-168.

50. Tsukada, T., K. Eguchi, K. Migita, Y. Kawabe, A. Kawakami, N. Mat- suoka, H. Takashima, A. Mizokami, and S. Nagataki. 1995. Transforming growth factor $\beta 1$ induces apoptotic cell death in cultured human umbilical vein endothelial cells with down-regulated expression of bcl-2. Biochem. Biophys. Res. Commun. 210:1076-1082.

51. Yang, X., N.F. Galeano, M. Szabolcs, R.R. Sciacca, and P.J. Cannon. 1996. Oxidized low density lipoproteins alter macrophage lipid uptake, apoptosis, viability, and nitric oxide synthesis. J. Nutr. 126(Suppl.):1072S-1075S.

52. Kiener, P.A., P.M. Davis, G.C. Starling, C. Mehlin, S.J. Klebanoff, J.A Ledbetter, and W.C. Liles. 1997. Differential induction of apoptosis by Fas-Fas ligand interactions in human monocytes and macrophages. J. Exp. Med. 185: 1511-1516.

53. Mitchinson, M.J., S.J. Hardwick, and M.R. Bennett. 1996. Cell death in atherosclerotic plaques. Curr. Opin. Lipidol. 7:324-329. 